\title{
Protecting the Right to Life of Journalists: The Need for a Higher Level of Engagement
}

\author{
Christof Heyns* \& Sharath Srinivasan**
}

\begin{abstract}
Journalists play a central role in fostering a society based on the open discussion of facts and the pursuit of the truth, as opposed to one based on rumor, prejudice, and the naked exercise of power. As a result, journalists are often literally in the line of fire, and deserve special protection. This article considers the characteristics of deadly attacks on journalists over the last two decades, and examines how the applicable legal and policy frameworks can be used better or improved to provide a higher level of protection. Impunity, often a by-product of the politicized nature of journalistic activities, is seen as the major cause of continuous attacks on journalists. The conclusion is drawn that one of the key elements of a strategy to better protect journalists is to "elevate" the issue on a number of fronts: to move prevention and accountability from the local to the central level within domestic jurisdictions, while simultaneously heightening the level of international engagement with this issue.
\end{abstract}

* Christof Heyns, Professor of Human Rights Law and Co-Director, Institute for International and Comparative Law in Africa, Faculty of Law, University of Pretoria; United Nations Special Rapporteur on extrajudicial, summary or arbitrary executions.

** Sharath Srinivasan, David and Elaine Potter Lecturer and Director, Centre of Governance and Human Rights, Department of Politics and International Studies, University of Cambridge; Fellow, King's College Cambridge.

The article draws on a report delivered by the United Nations Special Rapporteur on extrajudicial, summary or arbitrary executions to the Human Rights Council on 19 June 2012, U.N. Doc. A/HRC/20/22, which in turn benefited from work done by the staff of the mandate in Geneva (in particular Alice Mauske and Orest Nowosad) and Pretoria (in particular Gus Waschefort and Romi Brammer) and a research team at the Centre of Governance and Human Rights, University of Cambridge, UK (led by Sarah Elliot and Mona Elbahtimy). Participants in an expert meeting on the topic organized by the Centre in Cambridge on 1 and 2 March 2012 enriched the contents. The article reflects the personal opinions of the authors. 


\section{CONTEXT}

The heightened power of information in the modern age has resulted in news and journalism becoming an increasingly contested domain. Journalists often deal with outside influences on and censorship of their work, but to an alarming extent they also find themselves under personal attack. Journalists around the world and those close to them often face physical danger ranging from threats, attempted or actual assaults, abductions, disappearances, and even death. ${ }^{1}$ If journalists are deliberately targeted, or if those who attack them go unpunished, the media cannot be free.

The most extreme form of censorship is to kill a journalist. Killing not only silences the voice of the particular journalist, but it also intimidates other journalists and the public in general, many of whom resort to exercising self-censorship through what is called the "chilling effect." As a result, the free flow of ideas and information is bottled and replaced by the stagnant and silent warning of the grave.

Probably the worst incident of journalist carnage in history occurred in the Maguindanao Province of the Philippines on 23 November 2009. A total of thirty-two journalists were among those killed, and no one has yet been held accountable. ${ }^{2}$ The year 2012 was one of the bloodiest years on record in terms of journalist deaths, with an estimated seventy journalists having been killed. ${ }^{3}$

This article examines how legal and other protective measures may be used to better protect journalists, and those close to them.

Freedom of expression and the concomitant right to receive information are "meta rights" — rights upon which the realization of many other rights depend. ${ }^{4}$ They are also cornerstones of democracy, good governance, and accountability as well as a precondition for individuals and society to make informed decisions. In a world where journalists are not safe, decisionmaking is based on ignorance, superstition, and rumor while actions of the powerful go unchecked. The work of journalists is also essential to ensure accountability for, and thus deterrence of, human rights abuses. The tragic

1. See CPJ, available at http://www.cpj.org; see also UNESCO, Safety of Journalists, available at http://www.unesco.org/new/en/communication-and-information/freedom-ofexpression/safety-of-journalists/; see also UNESCO, Press Freedom: SAFETY of JOURNALISTS AND IMPUNITY (2007), available at http://unesdoc.unesco.org/images/0015/001567/156773e. pdf.

2. See Press Release, Bob Dietz, CPJ Asia Program Coordinator, Third Witness to Maguindanao Massacre Killed, available at http://cpj.org/blog/2012/06/third-witness-to-maguindanao-massacre-killed.php; see also Leading Suspect in Maguindanao Massacre Tries to get Charges Dropped, RWB, 11 Apr. 2011, available at http://en.rsf.org/philippinesleading-suspect-in-maguindanao-02-03-2011,38316.html.

3. See CPJ, supra note 1 .

4. The notion of meta-rights was discussed in Amartya Sen, The Right not to be Hungry, in The Rıght то FoOd 70-71 (Philip Alston \& Katarina Tomaševski eds., 1984). 
events during the last days of the civil war in Sri Lanka in 2009 is a case in point, when the government cleared the entire Northeastern part of the country of journalists and then killed up to 40,000 people. ${ }^{5}$ It is therefore not only a personal tragedy, but also a threat to society as a whole when journalists are killed or attacked because of their work.

Journalists deserve special concern not primarily because they perform heroic acts in the face of danger, although that is often the case, but because the social role they play is so important to society at large. Just as the shooting of a police officer warrants messages of "calling all units, officer down" throughout the police force, an attack on a journalist represents an assault on the foundations of the human rights project and on informed society as a whole. ${ }^{6}$ In this sense, freedom of expression is an individual as well as a collective right, and journalists provide a vital connective tissue that enables this. ${ }^{7}$ They are essential for a robust public sphere open to all that fosters reasoned debate and democratic accountability. As such, protection of journalists does not inherently promote a specific ideology; instead it preserves space for different voices to be heard, largely irrespective of what they have to say. When the specter of attacks forces journalists to retreat, this vital sphere for the protection of reason and rights is withered.

Recent research claims that violence worldwide has decreased significantly during the last four centuries. ${ }^{8}$ One of the reasons advanced for this development is the interconnectedness of the human race, which allows people from all parts of the world to understand and relate much better to each other than in any previous period in history. This is a development in which the media has played, and continues to play, a major role. It would be ironic, and dangerous to humanity as a whole, if those who help to make the world safer do not enjoy special attention.

One of the first questions to ask when considering ways to better protect journalists is: who is to be considered a journalist? Information and communication technology has developed to the extent that those who are today involved in the production and dissemination of information no longer do so only through the pages of newspapers or the sights and sounds of

5. UN, Report of the Secretary-General's Panel of Experts on Accountability in SRi Lanka (2011), available at http://www.un.org/News/dh/infocus/Sri_Lanka/POE_Report_Full.pdf

6. See The Safety of Journalists is an Issue that Affects Us All, supra note 1; see also COE, Human Rights and a Changing Media Landscape (2011), available at http://www.coe.int/t/ commissioner/Activities/themes/MediaFreedom/MediaLandscape2011.pdf.

7. Special Rapporteur on the Promotion and Protection of the Right to Freedom of Opinion and Expression, Report of the Special Rapporteur on the promotion and protection of the right to freedom of opinion and expression, U.N. Doc. A/HRC/14/23, at 29 (2010) (by Frank La Rue).

8. See Steven Pinker, The Better Angels of Our Nature: Why Violence Has Declined 299 (2011); see also UN Office on Drugs and Crime, Global Study on Homicide 2011 (2011), available at http://www.unodc.org/documents/data-and-analysis/statistics/Homicide/Globa_study_ on_homicide_2011_web.pdf. 
television or radio. The internet in various forms, such as websites, blogs, and social networks, plays an increasingly integral role in the distribution of information. Newspapers also increasingly rely on the internet to reach their readers, and some have ceased publication in hard copy or reduced its scale. ${ }^{9}$ Moreover, the rise of user-generated content has enabled a complex intermingling of the contributions of professional journalists and vocal citizens in the production of news and analysis. However, there is no point in saying that everyone who uses the internet or social media is a journalist who deserves special protection. If everyone is a journalist and therefore worthy of special protection, then in effect no one is. The question becomes how to identify those who play the role described above and are in danger as a result.

The following definition reflects a functional approach that is widely accepted: "The term 'journalist' means any natural or legal person who is regularly or professionally engaged in the collection and dissemination of information to the public via any means of mass communication." ${ }^{10}$ This definition includes the "new media" or "citizen and online journalists."11 Reporters, photographers, and those who directly support their profession, such as stringers and drivers, should be seen in the same light.

\section{STATISTICAL OVERVIEW}

How prevalent is the problem affecting this growing and diverse group of people? What are its characteristics? As will be demonstrated below, an alarming number of journalists are subjected to physical violence or are killed each year in the course of their duties. Mere casualty figures do not fully convey the extent of the problem. In many cases, journalists are prevented

9. Dan Hind, The Future of News, AlJAZEERA, 14 July 2012, available at http://www.aljazeera. com/indepth/opinion/2012/07/201271213102791856.html.

10. COE, Rec. No. R (2000) 7, Committee of Ministers To Member States on the Right of Journalists not to Disclose Their Sources of Information (adopted 8 Mar. 2000), available at http://www.coe.int/t/dghl/standardsetting/media/doc/cm/rec\%282000\%29007\&expmem EN.asp; see also General Comment No. 34, Article 19: Freedoms of Opinion and Expression, General Remarks, adopted 12 Sept. 2011, U.N. GAOR, Hum. Rts. Comm., 102d Sess., 9 44, U.N. Doc. CCPR/C/GC/34 (2011), where journalism is defined as "a function shared by a wide range of actors, including professional full-time reporters and analysts, as well as bloggers and others who engage in forms of self-publication in print, on the internet or elsewhere."

11. Special Rapporteur on the Promotion and Protection of the Right to Freedom of Opinion and Expression, Report of the Special Rapporteur on the Right to Freedom of Opinion and Expression, Hum. Rts. Council, I 4, U.N. Doc., A/HRC/20/17 (2012) (by Frank La Rue). Not all journalists focus on human rights - they shine their light on a wide range of issues. Since some journalists are human rights defenders and some human rights defenders are journalists, these two categories are overlapping but not identical. 
from doing their work because of the threats to their safety or the safety of others that may not be realized or they do not lead to death. Nevertheless, the available statistics on the killing of journalists (especially when measured over time) provide an important and compelling starting point to help better understand the broader problem of the physical intimidation of journalists and to identify ways to reduce the danger.

A number of civil society groups are doing the important work of tracking and categorizing work-related deaths of journalists around the world, although data differs according to what is being monitored. Some, like the International News Safety Institute (INSI) and the International Federation of Journalists (IFJ), keep track of all safety-related aspects of the work of journalists, including vehicle accidents and illness. ${ }^{12}$ Others, such as the Committee to Protect Journalists (CPJ) and Reporters Without Borders (RWB) take a more narrow approach, that focuses on instances where journalists suffer violent deaths directly related to their profession. ${ }^{13}$ The present discussion will also analyze this narrower group of cases.

According to CPJ, in just over two decades between January 1992 and February 2013, 971 journalists suffered violent deaths directly related to their work. In 88 percent of murder cases, amounting to 588 deaths, there has been total impunity. The twenty deadliest places during that period, according to CPJ, were as follows: Iraq: 151 killings; Philippines: seventy-three; Algeria: sixty; Russian Federation: fifty-four; Pakistan: fifty-one; Somalia: forty-nine; Colombia: forty-four; Syria: thirty-two; India: twenty-nine; Mexico: twenty-eight; Afghanistan: twenty-four; Brazil: twenty-four; Turkey: twenty; Bosnia and Herzegovina: nineteen; Sri Lanka: nineteen; Rwanda: seventeen; Tajikistan: seventeen; Sierra Leone: sixteen; Bangladesh: thirteen; and Israel and the Occupied Palestinian Territory: twelve. ${ }^{14}$

Some of the most telling figures are provided below, as recorded by CPJ. ${ }^{15}$

\section{A. Kind of Work Performed}

In terms of the kinds of work performed by those killed over the past two decades, print and broadcast reporters by far represent those most affected, at a combined total of fifty-three percent of the casualties. ${ }^{16}$

The full picture, reflecting some overlap between categories, looks as follows:

12. See generally INSI, available at http://www.newssafety.org; see IFJ, Press Freedom and Safety, available at http://www.ifj.org/en/pages/press-freedom-safety.

13. See CPJ, Our Research, available at http://www.cpj.org/ about/research.php; see RWB, The 10 Most Dangerous Places for Journalists, available at http://www.rsf.org/annualoverview-21-12-2011,41582.html.

14. CPJ, 971 Journalists Killed Since 1992, available at http://www.cpj.org/killed/.

15. Id.

16. Id. 


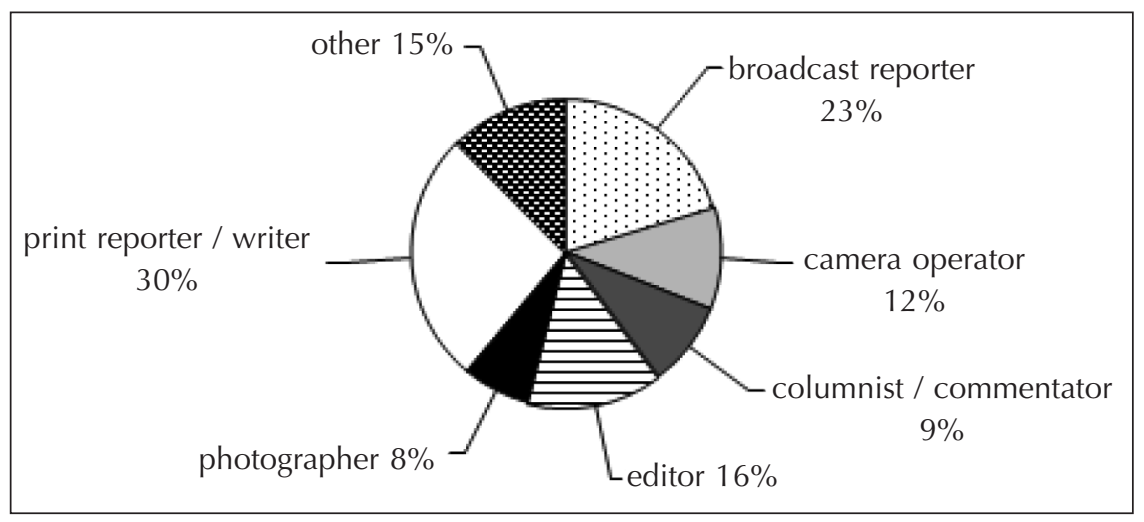

\section{B. Type of Media Involved}

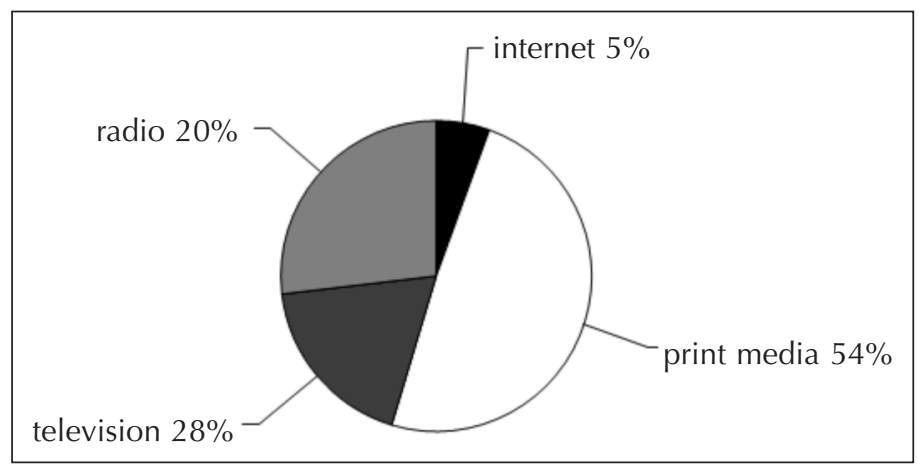

The figure of 5 percent average for the internet over the last twenty years has gone up considerably during recent years, and reached 19 percent 36 percent in $2012 .{ }^{17}$

\section{Gender Breakdown}

A total of 94 percent of those killed were men, while 6 percent were women. ${ }^{18}$ However, women are exposed to other forms of gender specific violence that may not be lethal. 


\section{Local/Foreign Correspondents}

Often the media spotlight is on international reporters, especially in situations of armed conflict or large-scale violence. However, local journalists are most often the ones in harm's way. Out of those killed, 87 percent were local journalists, 13 percent foreign. An overall 16 percent were freelance journalists. ${ }^{19}$

\section{E. Topics or Beats Covered}

Contrary to popular belief, journalists (mostly local ones) covering domestic issues are more at risk than war correspondents. Coverage of local politics, human rights, organized crime, and corruption often focuses on figures of authority or wielders of power, who do not appreciate the scrutiny. Reliance on local authorities for prevention and protection becomes more challenging.

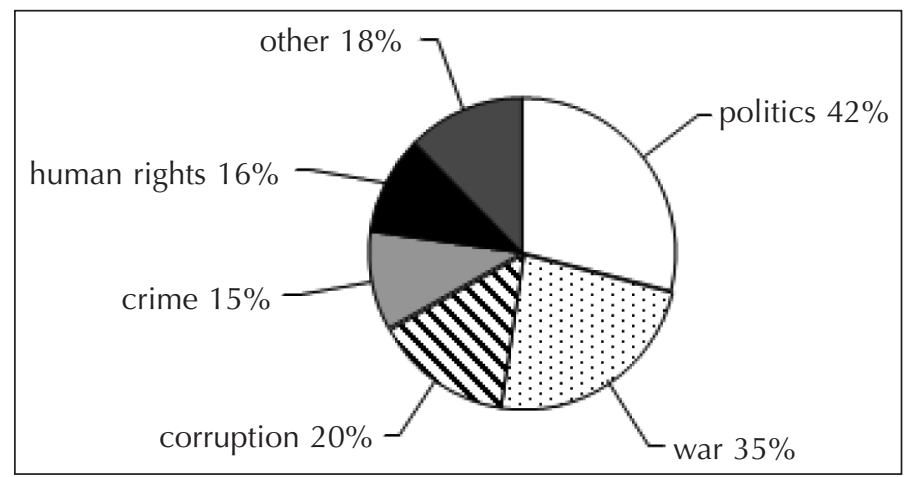

\section{F. Context of Killing}

Murder is the predominate method used for journalists killings, at approximately 68 percent. In addition, 19 percent of cases took place in the context of crossfire/combat and 13 percent occurred during dangerous assignments. ${ }^{20}$ The overriding problem is therefore deliberate and targeted killing rather than accident.

19. Id.

20. Id. at 5 . 


\section{G. Suspected Source of Fire in the Case of Murder}

The suspected source of the lethal action - whether gunshots or otherwise - in the case of murder (crossfire is therefore excluded) is as follows: in 30 percent of cases, political groups were believed to be the source of lethal actions; 23 percent of cases involved government officials; 13 percent criminal groups; 6 percent paramilitary groups; 5 percent military officials; 2 percent local residents; 2 percent mob violence; and in 19 percent of cases the source was unknown. ${ }^{21}$ This highlights perhaps the most difficult challenge to overcome in enhancing protection of journalists' right to life and a major contribution towards impunity: often the suspects are drawn from the very institutions and authorities responsible for upholding and enforcing a protective regime. The strength of that regime, its internal accountability mechanisms, and the attention given to it at the highest levels becomes vital.

\section{H. Warning Signs for Murder}

The statistics covering the last twenty years also point to the importance and possibility of pre-emptive protection. Where journalists were murdered, in the period before the event 36 percent of cases involved journalists being threatened; 22 percent had been taken captive; and 13 percent had been tortured. ${ }^{22}$ As will be highlighted below, during recent years the number of journalists who are known to have received threats in the weeks before they were killed has risen considerably.

\section{Accountability and Impunity}

As noted previously, the level of complete impunity with respect to the murder of journalists during the last two decades has been extraordinarily high-88 percent. $^{23}$ 


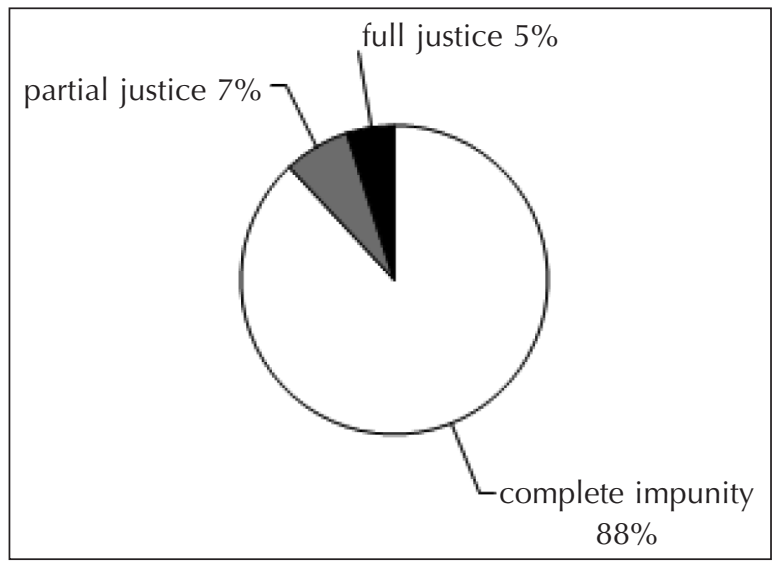

The correlation between impunity and the killing of journalists is evident from the fact that the countries where the numbers of journalists killed are consistently high over time are also, almost without exception, those with the highest level of impunity. ${ }^{24}$ Impunity over time is a major, if not the main, cause of the consistently high number of journalists killed every year. In some cases impunity may be genuinely caused by a lack of evidence. Although in many cases, all indications are that impunity is intentional. There is a lack of political will to prosecute, or indeed there is political protection of the perpetrators.

The foregoing statistics reveal clearly that the most common profile of a journalist who is killed is a local correspondent, covering politics or corruption for a newspaper or a radio station. The plight of foreign war correspondents attracts the most attention and is worthy of all the concern it receives. However, special attention must also be paid to the fates of local journalists-typified as someone who drives home after work and is intercepted by two people on a motorbike, one holding a gun.

While the practice of killing the messenger is not new, the nature of the threat changes as society changes. As was suggested above, the increased importance of information and control over information in the modern world heightens the risks that journalists face. Attention was also drawn to the fact that the news is now increasingly disseminated by journalists online. Both

24. CPJ, Getting Away with Murder, available at http://www.cpj.org/reports/2011/06/2011impunity-index-getting-away-murder.php\#index. The statistics on impunity concerning the killing of journalists will be more compelling if they are compared to statistics concerning the general level of accountability for killings in that particular population. However, such statistics are not available. 
professionals and laypeople use social media. In parts of Mexico, for example, the conventional media have for all practical purposes been replaced by new digital media and assassins have likewise moved their sights, with troubling ease. ${ }^{25}$ With the widening of the pool of who are now considered to be journalists, there has been an increase in the number of potential targets for those who want to control the flow of information. Increased fatalities among photojournalists are another worrying trend, indicating recognition of the growing impact of increasingly transmissible visual imagery. There have also been a number of high-profile killings of environmental journalists in recent years, whose stories often contain information about corruption involving multinational corporations. ${ }^{26}$

Significantly, around 70 percent of journalists murdered in 2011 are reported by some sources to have received threats in the weeks before they died. ${ }^{27}$ This suggests that there could be more preventative measures taken than is commonly appreciated. In an interconnected world, raising the alarm publicly can have a restraining effect, and one of the challenges is to find ways in which this can be done more effectively.

Are all deaths of journalists captured in the aforementioned statistics preventable? Probably not. Those who get close to crime and violence will always be at risk of being caught in the line of fire. Not all criminals can be deterred. However, the risks can be reduced if there is a greater recognition of the legitimacy of the presence of journalists in areas of conflict as well as covering dangerous and sensitive beats, if there is more robust protective regime with higher levels of accountability, and if the journalists themselves are better prepared. Recommendations will be made below to reduce the risks that journalists face.

It should also be noted that not all journalists adhere to the same ethical standards. For example, there are journalists who collaborate with criminal gangs. If during an armed conflict journalists become direct participants in the hostilities they cover, they are not specially protected from being targeted. Journalists, like other people, are subject to the law, and as such may be held accountable or be unprotected. However, the appropriate reaction, even in those cases where journalists fall foul of the law, or do not adhere to professional ethics, can never be arbitrary execution.

25. RWB, Fourth Netizen Murdered in Two Months in Nuevo Laredo: Cartels Feared (14 Nov. 2011), available at http://en.rsf.org/mexique-fourth-netizen-murdered-intwo-14-11-2011,41385.html.

26. See, e.g., Article 19, Indonesia: Journalists Risk Lives for Reporting on Environmental Impacts and Local Politics, available at http://www.article19.org/resources.php/resource/ 1602/en/indonesia:-journalists-risk-lives-for-reporting-on-environmental-impacts-andlocal-politics.

27. CPJ, AtTACKS On the Press In 2011 (2011), available at http://www.cpj.org/2012/02/attackson-the-press-in-2011-journalists-killed-an.php. 
The statistical overview outlined above gives an opportunity to assess possible interventions to ensure greater safety for journalists. In this context it may be useful to ask the question why international journalists are targeted less often, and to see whether this provides any clues as to how local journalists can be better protected. One answer could be that there is greater reluctance to harm international journalists because of the global attention and possible unforeseen and unforeseeable consequences. To target a foreign correspondent who is part of an international web of actors often carries a higher risk of repercussions, not least because it entails the uncertainty of involving third parties, including an outside state or other foreign actors, who may be in a position to pressure the national authorities to ensure accountability. By contrast, local journalists are often isolated and as a result more vulnerable. Moreover, international journalists are in many cases better placed to respond to threats against them, either by getting evacuated or drawing the attention of the authorities to their plight, through the recourse they have to their home governments or media organizations. They also often receive special safety as well as first aid training, and have protective equipment.

If this assessment is correct, one way of enabling greater safety for those most at risk over and above access to better training and equipment will be to ensure that they can attract attention outside the local realm. The approach should be to guarantee a higher level of attention, or to "elevate the issue," by finding ways to place the safety of local journalists more squarely on the broader national and international agenda, and to deter those who wish to harm them through the knowledge that there may as a result be repercussions emanating from outside forces. Elevating the issue relates to promoting greater awareness of the position of journalists in general and to the plight of individual journalists in particular. What is required is a reverse chilling effect-perpetrators and those who protect them must get the message that at the local and international level the cost of attacks against journalists will rise. It should be made clear, however, that engagement from a higher level is to be done as a second layer of protection in addition to what is done on the local or governmental level, where the primary responsibility lies.

\section{THE PROTECTIVE FRAMEWORK}

A variety of mechanisms exist to protect journalists from harm, and to provide accountability where these protections fail. The global and UN human rights systems, as well as the regional human rights mechanisms (in those parts of the world where they are in operation), are designed to ensure attention is given to such issues on the international level. States, to a greater or lesser extent, also have systems to protect journalists on the domestic level. The main entry points and better ways to protect them better will now be considered. 


\section{A. The Right to Life and the Other Rights Concerned}

There is no specific international treaty dedicated to the protection of journalists from physical attacks. Various parts of the international system collectively play this role. Most pertinently, the right to life is recognized as a rule of customary international law, ${ }^{28}$ and is listed specifically in Article 3 of the Universal Declaration of Human Rights (UDHR) and Article 6 of the International Covenant on Civil and Political Rights (ICCPR). It is a right that may not be derogated from in times of emergency, such as war. ${ }^{29}$ For this reason, the right to life is widely recognized as the "supreme right," 30 while the intentional taking of life could likewise be regarded as the "supreme crime."

A wider network of rights is also relevant to enhancing journalists' bodily security in exercising their profession, such as the rights to physical integrity, not to be tortured or arbitrarily detained, and the right not to be disappeared, in addition to the rights to freedom of expression and to information. ${ }^{31}$ Violations of these rights are often early warnings that journalists' lives may be at risk and a comprehensive strategy must keep this in mind.

International human rights law, at the global as well as the regional levels, requires states to respect and protect the lives of all within their jurisdiction from attacks and threats of attacks, and to provide an effective remedy where this has not been the case. The state and its agents are not only required to refrain from engaging in arbitrary killings, but also to protect people from such threats by non-state actors. ${ }^{32}$

28. Special Rapporteur on Extrajudicial, Summary or Arbitrary executions, Report of the Special Rapporteur on Extrajudicial, Summary or Arbitrary Executions, 9 43, U.N. Doc. A/HRC/17/28 (2011) (by Christof Heyns).

29. UDHR, adopted 10 Dec. 1948, G.A. Res. 217A (III), U.N. GAOR, 3d Sess., art. 3, U.N. Doc. A/RES/3/217A (1948); ICCPR, G.A. Res. 2200A (XXI), U.N. GAOR, 21st Sess., Supp. No. 16, art. 6, U.N. Doc. A/6316 (1966); see also American Convention on Human Rights, signed 22 Nov. 1969, art. 27, O.A.S. Doc. OEA/Ser.L/V/II.23, doc. 21, rev. 6 (1979), O.A.S.T.S. No. 36, 1144 U.N.T.S. 143 (entered into force 18 July 1978); see also European Convention on Human Rights, opened for signature 4 Nov. 1950, art.15, 213 U.N.T.S. 221, Eur. T.S. No. 5 (entered into force 3 Sept. 1953) [hereinafter ECHR]; see also Arab Charter on Human Rights, League of Arab States, art. 4, ๆ 2, 15 Sept. 1994, available at http://www.unhcr.org/refworld/docid/3ae6b38540.html; see also Legality of the Threat or Use of Nuclear Weapons, 1996 I.C.J. 15 I 25 (8 Jul.); see also General Comment No. 6, The Right to Life, U.N. GAOR, Hum. Rts. Comm., 16th Sess., U.N. Doc. HRI/GEN/1/Rev.1, at 6 (1982); Herrera Rubio v. Colombia, Human Rights Committee Communication No. 161/1983, adopted 2 Nov. 1987, U.N. GAOR, Hum. Rts. Comm., at 190, U.N. Doc. Supp. No. 40 (A/43/40) (1988).

30. See General Comment No. 6, supra note 29, ๆ 1.

31. ICCPR, supra note 29, arts. 7, 9, 19; International Convention for the Protection of All Persons from Enforced Disappearance, adopted 20 Dec. 2006, G.A. Res. 61/177, U.N. GAOR, 61st Sess., U.N. Doc. A/Res/61/177 (2007) (entered into force 23 Dec. 2010).

32. See General Comment No. 31 [80], The Nature of the General Legal Obligation Imposed on States Parties to the Covenant, CCPR HRC Res. 80/31, at 8, U.N. Doc. CCPR/C/21/ Rev.1/Add.13 (2004). 
Impunity, as has been noted, is widely recognized as one of the main causes of the continued killing of journalists. One of the elements of the right to life is accountability where a breach has occurred. It is an inherent aspect of the state's due diligence obligation to prevent and investigate threats and subsequently punish those who made them, which would provide redress to victims, and violations of the right to life. ${ }^{33}$ The Principles on the Effective Prevention and Investigation of Extra-legal, Arbitrary and Summary Executions ${ }^{34}$ provide that investigations in instances of extrajudicial executions are to be "thorough, prompt and impartial" and conducted by independent bodies. ${ }^{35}$ Prosecutors are also required to act independently, impartially, and expeditiously. ${ }^{36}$ States are obliged to enable prosecutors to act independently and free from interference, including, where necessary, ensuring the safety of prosecutors. ${ }^{37}$ Victims should also be able to seek redress through civil remedies, regardless of whether a criminal act has been established.

The European Court of Human Rights has determined that an investigation: should be initiated by the state of its own volition; should be independent, effective, sufficiently open to public scrutiny, and reasonably prompt; and should involve the next of kin or family. ${ }^{38}$ According to the Court, "any deficiency in the investigation which undermines its ability to identify the perpetrator or perpetrators will risk falling foul of this standard." ${ }^{39} \mathrm{~A}$ parallel jurisprudence has been developed by the Inter-American Court of Human Rights and in the African Commission on Human and Peoples' Rights. ${ }^{40}$ Impunity, in other words, can also constitute a violation of the right to life. ${ }^{41}$

33. See General Comment No. 6, supra note 29; see also Herrera Rubio v. Colombia, supra note 29, 10.3; see also Principles on the Effective Prevention and Investigation of Extra-legal, Arbitrary and Summary Executions, U.N. ESCOR Res. 1989/65, annex, U.N. Doc E/1989/89 (1989); Special Rapporteur on Extrajudicial, Summary or Arbitrary executions, Report of the Special Rapporteur on Extrajudicial, Summary or Arbitrary Executions, U.N. Doc. E/CN.4/2005/7 (2004) (by Philip Alston).

34. U.N. ESCOR Res. 1989/65, supra note 33.

35. Id. ๆ ๆ 7, 9; see McCann v. United Kingdom, A-324 Eur. Ct. H.R. ๆ ๆ 161-64 (1995); Hum. Rts. Comm. Communication No. 146/1983, Baboeram-Adhin et al v. Suriname, views adopted 4 Apr. 1985; see also Velásquez Rodríguez v. Honduras, Rep. Inter-Am. Ct. H.R., OAS/Ser. L./V./III.19, Doc. 13 (1988), 28 I.L.M. (1989), at 291; U.N. Doc. E/ CN.4/2005/7, supra note 33, ๆ $972-75$.

36. Guidelines on the Role of Prosecutors, Eighth United Nations Congress on the Prevention of Crime and the Treatment of Offenders, at 12-13, 27 Aug.-7 Sept. 1990, available at http://www1.umn.edu/humanrts/instree/i4grp.htm.

37. Id. at 5 .

38. SeeTanrikulu v. Turkey, 1999-IV Eur. Ct. H.R. 457; Osman v. United Kingdom, 1998-VIII, No. 95 Eur. Ct. H.R 3124; Ergi v. Turkey, 1999-IV Eur. Ct. H.R.; Nachova v. Bulgaria, 2005-VII, Eur. Ct. H.R 1 (endorsed by the Grand Chamber in its Judgment of 6 July 2005); see also Piersack v. Belgium, A-053 Eur. Ct. H.R. (1982).

39. Ramsahai v. Netherlands, Grand Chamber, Eur. Ct. Hum. Rts., I 324 (2007).

40. Mack Chang v. Guatemala, Inter-Am. Ct. H.R. (Ser. C) No. 101 (25 Nov. 2003); Velásquez Rodríguez, supra note 35; The Constitutional Rights Project v. Nigeria, Annex V, African Com. on H. and People's R. 183 (1995), ๆ 14.

41. General Comment No. 31, The Nature of the General Legal Obligation Imposed on States Parties to the Covenant, adopted 29 Mar. 2004, U.N. GAOR, Hum. Rts. Comm., 80th Sess., 2187th mtg., I 18, U.N. Doc. CCPR/C/21/Rev.1/Add.13 (2004). 
The mechanisms available that can be invoked to protect these rights and to elevate the plight of journalists to a higher level of engagement will now be discussed.

\section{UN Level}

There are a number of platforms available in the UN that have been used to deal with the issue of the safety of journalists, and that provide entry points for further action. The Secretary-General has on various occasions condemned the killing of journalists, ${ }^{42}$ as has the Human Rights Council in its resolutions, including in a comprehensive recent resolution on 27 September 2012. ${ }^{43}$ The targeting of journalists in a number of countries has been addressed under the universal periodic review mechanism. ${ }^{44}$ The High Commissioner for Human Rights has also condemned attacks against journalists in specific countries. ${ }^{45}$

42. See U.N. Secretary-General, Report of the Secretary-General on the Protection of Civilians in Armed Conflict, U.N. SCOR, I 29-30, U.N. Doc. S/2007/643 (2007); U.N. Secretary-General, Report of the Secretary-General on the Protection of Civilians in Armed Conflict, U.N. SCOR, ब 19, U.N. Doc. S/2009/277 (2009); U.N. Secretary-General, Report of the Secretary-General on the Protection of Civilians in Armed Conflict, U.N. SCOR, I 16, U.N. Doc. S/2010/579 (2010); U.N. Secretary-General, The Situation in Afghanistan and Its Implications for International Peace and Security, U.N. GAOR, I 34, U.N. Doc. A/56/681-S/2001/1157 (2001); U.N. Secretary-General, The Situation in Afghanistan and Its Implications for International Peace and Security, U.N. GAOR, I 44, U.N. Doc. A/61/326-S/2006/727 (2006); U.N. Secretary-General, The Situation in Afghanistan and Its Implications for International Peace and Security, U.N. GAOR, 9 53, U.N. Doc. A/62/345-S/2007/555 (2007); U.N. Secretary-General, The Situation in Afghanistan and Its Implications for International Peace and Security, U.N. GAOR, If 50, U.N. Doc. A/63/372-S/2008/617 (2008).

43. H.R.C. Res. 21/3, at 1-3, U.N. Doc. A/HRC/21/L.6 (2012). See also Resolutions 12/16, at 3; A/HRC/RES/S-15/1, at 3; A/HRC/RES/S-16/1, at 1-2; A/HRC/RES/S-17/1, at 5; A/ $\mathrm{HRC/RES} / \mathrm{S}-18 / 1$, at 2 (a).

44. See the respective annual reports of the Human Rights Council: Report of the Human Rights Council on its Eighteenth Session, H.R.C., U.N. GAOR, Hum. Rts. Council, at I I 319, 321, U.N. Doc. A/HRC/18/2 (2011) (advance unedited version), (Somalia); Report of the Human Rights Council on its Tenth Session, H.R.C., U.N. GAOR, Hum. Rts. Council, at 9 651, 662, U.N. Doc. A/HRC/10/29, (Colombia); Report of the Human Rights Council on its Eleventh Session, H.R.C., U.N. GAOR, Hum. Rts. Council, at I 609, 616, U.N. Doc. A/HRC/11/37, (Mexico); Report of the Human Rights Council on its Sixteenth Session, H.R.C., U.N. GAOR, Hum. Rts. Council, at 9 525-26, U.N. Doc. A/HRC/16/2, (Honduras); Report of the Human Rights Council on its Eighth Session, H.R.C., U.N. GAOR, Hum. Rts. Council, at I 473-74 U.N. Doc. A/HRC/8/52, (Philippines).

45. C.H.R. Res.57/3, ๆ 38, 191-94, U.N. Doc. E/CN.4/2001/15 (2001); C.H.R. Res. 59/3, ब 111, U.N. Doc. E/CN.4/2003/13 (2003); C.H.R. Res. 60/3, ब 97-98 U.N. Doc. E/ CN.4/2004/13 (2004); C.H.R. Res. 61/3, Corr.1, Annex II, ๆ 14, Annex IV, ๆ 12, U.N. Doc. E/CN.4/2005/10 (2005); C.H.R. Res. 62/3, I ๆ 61, 87, Annex III, I ๆ 40-43, 54, U.N. Doc. E/CN.4/2006/9 (2006); C.H.R. Res. 4/2, ๆ ๆ 11, 44-45, 109, 124, Annex II, ๆ ๆ 30-32, U.N. Doc. A/HRC/4/48 (2008); C.H.R. Res. 7/2, ๆ ๆ 68-69, Annex, ๆ ๆ 19-20, 27, U.N. Doc. A/HRC/7/39 (2008); C.H.R. Res. 10/2, I ๆ 33, 51-54, U.N. Doc. A/HRC/10/23 (2009); C.H.R. Res. 13/10, ๆ 9 9, 55-59, 69 (f), U.N. Doc. A/HRC/13/62 (2010). 
Different special procedures appointed by the Human Rights Council have dealt with the same issue. ${ }^{46}$ Special procedures have the ability to move fast, have the mandate to cover all countries (not only those that have ratified particular human rights treaties), and do not require the exhaustion of domestic remedies. They often send letters of allegation to states where journalists have been killed, as a way of promoting accountability. Of particular importance to the issue of prevention is the fact that they also have the power to send urgent appeals to states where journalists and others are under threat, in order to urge those states to protect the person in question. It is an important access point that is currently underutilized. ${ }^{47}$

In an important consideration of the applicable principles, the Human Rights Council adopted, without a vote a resolution, on the Safety of Journalists on 21 September 2012. ${ }^{48}$

The Human Rights Committee has explicitly addressed the safety of journalists in General Comment No. 34 (2011) on the freedoms of opinion and expression. ${ }^{49}$ In Afuson Njaru v. Cameroon, the Committee found that the state had violated Article 9 of the ICCPR (right to security of the person) by failing to take measures against attacks on journalists. ${ }^{50}$ In recent years the Human Rights Committee, in its concluding observations, has expressed

46. See Special Rapporteur on the Promotion and Protection of the Right to Freedom of Opinion and Expression, Report of the Special Rapporteur on the Promotion and Protection of the Right to Freedom of Opinion and Expression, U.N. GAOR, 20th Sess., U.N. Doc. A/HRC/20/17/Add.1 (2012) (by Frank La Rue); U.N. Secretary-General, Promotion and Protection of the Right to Freedom of Opinion and Expression, U.N. GAOR, 65th Sess., I 20, U.N. Doc. A/65/284 (2010); Special Rapporteur on the Situation of Human Rights Defenders, Report of the Special Rapporteur on the Situation of Human Rights Defenders, U.N. GAOR, 19th Sess., ๆ 9 29-59, U.N. Doc. A/HRC/19/55 (2011) (by Margaret Sekaggya).

47. It should be noted that the special procedures may not act merely on the basis of newspaper reports, but have to be approached by an individual, group, NGO, intergovernmental agency, or government, who must provide information regarding the incident, the victims of the incident, the alleged perpetrators and the source of the allegations. See OHCHR, Communications, available at http://www.ohchr.org/EN/HRBodies/SP/ Pages/Communications.aspx.

48. H.R.C. Res. 21/L6, U.N. Doc. A/HRC/21/L6 (2012).

49. General Comment No. 34, supra note 10, I 23.

States parties should put in place effective measures to protect against attacks aimed at silencing those exercising their right to freedom of expression. . . . Nor, under any circumstance, can an attack on a person, because of the exercise of his or her freedom of opinion or expression, including such forms of attack as arbitrary arrest, torture, threats to life and killing, be compatible with article 19. Journalists are frequently subjected to such threats, intimidation and attacks because of their activities. ... All such attacks should be vigorously investigated in a timely fashion, and the perpetrators prosecuted, and the victims, or, in the case of killings, their representatives, be in receipt of appropriate forms of redress. $I d$.

50. Views of the Hum. Rts. Comm. Under art. 5, I 4, of the Optional Protocol to the Int'l Covenant on Civil and Political Rts., Communication No. 1353/2005: Camaroon. 05/14/2007, 12-30 Mar. 2007,U.N. GAOR, Hum. Rts. Comm., 89th Sess., ๆ 6.3 U.N. Doc. CCPR/C/89/D/1353/2005 (2007). 
concern about intimidation, harassment, and threats against journalists. ${ }^{51}$ The Committee against Torture has also expressed similar concerns. ${ }^{52}$

It should be noted, from the perspective of prevention, that the Human Rights Committee has the power to inform a state party that interim measures are "desirable to avoid irreparable damage" with respect to a pending complaint. ${ }^{53}$ This can, in appropriate cases, be used as a tool for prevention with respect to journalists. Other treaty bodies with comparable competences in this context are the Committee against Torture, the Committee on Enforced Disappearances, and the Committee on the Elimination of Discrimination against Women. ${ }^{54}$

The United Nations Educational, Scientific and Cultural Organization (UNESCO) has taken a lead role in the UN system in regards to freedom of expression, including the safety of journalists. For example, in 1997 UNESCO adopted Resolution 29 on the condemnation of violence against journalists. ${ }^{55}$ On a regular basis, UNESCO publicly condemns the killing of journalists ${ }^{56}$ and exercises "quiet diplomacy;" 57 it does so also with respect

51. H.R.Comm. Res. 79, I 8, U.N. Doc. CCPR/CO/79/PHL (2003); H.R.Comm. Res. 79, I 22, U.N. Doc. CCPR/CO/79/RUS (2003); H.R.Comm. Res. 97, ๆ 16, U.N. Doc. CCPR/C/RUS/CO/6 (2009) ; H.R.Comm. Res. 80, ๆ 11, U.N. Doc. CCPR/CO/80/COL (2004); H.R.Comm. Res. 99, ब 17, U.N. Doc. CCPR/C/COL/CO/6 (2010); H.R.Comm. Res. 88, ๆ 17, U.N. Doc. CCPR/C/HND/CO/1 (2006); H.R.Comm. Res. 96, ๆ 15, U.N. Doc. CCPR/C/AZE/CO/3 (2009); H.R.Comm. Res. 98, ๆ 20, U.N. Doc. CCPR/C/MEX/ CO/5 (2010); H.R.Comm. Res. 101, I 21, U.N. Doc. CCPR/C/SRB/CO/2 (2011).

52. Consideration of Reports Submitted by States Parties Under Article 19 of the Convention, U.N. GAOR, Comm. Against Torture, 44th Sess., ๆ 18, U.N. Doc. CAT/C/CMR/ CO/4 (2010); Consideration of Reports Submitted by States Parties Under Article 19 of the Convention, U.N. GAOR, Comm. Against Torture, 38th Sess., I 17, U.N. Doc. CAT/C/UKR/CO/5 (2007); Consideration of Reports Submitted by States Parties Under Article 19 of the Convention, U.N. GAOR, Comm. Against Torture, 42nd Sess., I 11, U.N. Doc. U.N. Doc. CAT/C/PHL/CO/2 (2009); Consideration of Reports Submitted by States Parties Under Article 19 of the Convention, U.N. GAOR, Comm. Against Torture, I 22, U.N. Doc. CAT/C/RUS/CO/4 (2009); Official Records of the General Assembly, 56th Sess., I 72, U.N. Doc. A/56/44 (2000/2001).

53. Rules of procedure of the Human Rights Committee, Rule 92, U.N. Doc. CCPR/C/3/ Rev.3 (1994).

54. Convention Against Torture and other Cruel, Inhuman or Degrading Treatment or Punishment, Rules of Procedure No. 114, Comm. Against Torture, U.N. Doc. CAT/C/3/ Rev.5 (2011); International Convention for the Protection of All Persons from Enforced Disappearance, adopted 20 Dec. 2006, G.A. Res. 61/177, U.N. GAOR, 61st Sess., art. 30(3), 31(4), U.N. Doc. A/Res/61.177 (2007) (entered into force 23 Dec. 2010); The Convention on the Elimination of All Forms of Discrimination against Women, Optional Protocol, Rules of Procedure No. 63, CEDAW Comm. U.N. Doc. A/56/38 (2013).

55. Resolution 29 "Condemnation of Violence Against Journalists," UNESCO (Nov. 1997), available at http://www.unesco.org/new/fileadmin/MULTIMEDIA/FIELD/Brussels/pdf/ ipdc_resolution_29.pdf.

56. See CPJ, supra note 1; see also UNESCO, Safety of Journalists, supra note 1.

57. UNESCO, UN Plan of Action on the Safety of Journalists and the Issue of Impunity (2012), available at http://www.unesco.org/new/fileadmin/MULTIMEDIA/HQ/CI/Cl/pdf/official_documents/un_plan_action_safety_en.pdf. 
to threats. The Belgrade Declaration on Support to Media in Violent Conflict and Countries in Transition ${ }^{58}$ and the Medellín Declaration on Securing the Safety of Journalists and Combating Impunity inform the direction followed by UNESCO. ${ }^{59}$

As of this writing, UNESCO is currently developing a major inter-agency framework, the UN Plan of Action on the Safety of Journalists and the Issue of Impunity. This will include pilot projects in a number of countries. ${ }^{60} \mathrm{At}$ its twenty-sixth session, in 2008, the Intergovernmental Council of the International Programme for the Development of Communication (IPDC) of UNESCO adopted its first Decision on the Safety of Journalists and the Issue of Impunity, in which member states were urged "to inform the DirectorGeneral of UNESCO, on a voluntary basis, of the actions taken to prevent the impunity of the perpetrators and to notify him of the status of the judicial inquiries conducted on each of the killings condemned by UNESCO." 61 There does not, however, appear to be sufficient civil society engagement with this process. Conceivably, nongovernmental organizations (NGOs) can prepare "shadow reports" commenting on the claims about issues such as accountability that states make. ${ }^{62}$

With regard to the International Labour Organization (ILO), while journalists do not currently have their own sectoral convention recognizing the dangerous conditions under which they work, this may be an option for the future. ${ }^{63}$

The global and the regional systems have also joined forces to address the issue. For example, in June 2012 four global and regional mandates issued a "Joint declaration on crimes against freedom of expression." ${ }^{4}$

58. Belgrade Declaration (2004), available at http://www.unesco.org/new/en/communicationand-information/flagship-project-activities/world-press-freedom-day/previous-celebrations/worldpressfreedomday2009000000/belgrade-declaration/.

59. Medellin Declaration (2007), available at http://www.unesco.org/new/en/communicationand-information/flagship-project-activities/world-press-freedom-day/previous-celebrations/worldpressfreedomday2009000/medellin-declaration/.

60. See UneSCO, UN Plan of Action on the Safety of Journalists and the Issue of Impunity, supra note 57; UNESCO, Draft 2012-2013 of Operationalizing the UN Plan of Action on Safety of JOURNALISTS (2012), available at http://www.unesco.org/new/fileadmin/MULTIMEDIA/ $\mathrm{HQ} / \mathrm{Cl} / \mathrm{Cl} / \mathrm{images} /$ Themes/Freedom_of_expression/Operationalizing_the_UN_Plan_of_Action_on_Safety_of_Journalists_v_15Nov2012.pdf.

61. UnESCO, Report by the Director-General to the Intergovernmental Council of the International Programme for the Development of Communication, Cl-10/CONF.202/4/Bis 2, I d 30 (2010), available at http://unesdoc.unesco.org/images/0018/001874/187491e.pdf.

62. In addition to the above, World Press Freedom Day (3 May annually) proclaimed by the General Assembly at the initiative of UNESCO, provides a rallying point to emphasize the right to life of journalists. UN Special Rapporteur on Freedom of Opinion and Expression, Article 19, Joint Declaration on Crimes Against Freedom of Expression, I 1, 4 (25 June 2012), available at http://www.article19.org/resources.php/resource/3348/ en/joint-declaration-on-crimes-against-freedom-of-expression.

63. See Sectoral Standards, available at http://www.ilo.org/sector/Resources/sectoral-standards/lang--en/index.htm.

64. Article 19, Joint Declaration on Crimes Against Freedom, supra note 62. 


\section{Regional Level}

Under all three established regional human rights systems-in Europe, the Americas, and Africa-individual cases may be brought to a regional court (and in two instances, commissions) concerning the rights protected in those systems, which include the right to life and physical integrity. ${ }^{65}$ This means, on the accountability front, that cases may be brought against state parties when there is a failure to respond effectively to threats to the life of a journalist, or when there is impunity when a journalist has been killed. The decisions of these courts are legally binding.

A number of decisions concerning the right to life of journalists have been handed down by the European Court of Human Rights. ${ }^{66}$ In Dink $v$. Turkey, the Court held that abandoning a charge against policemen for negligence in protecting journalist Hrant Dink was a failure by the state to protect the journalist. ${ }^{67}$

The Parliamentary Assembly of the Council of Europe (COE) has adopted various resolutions and recommendations on the issue. ${ }^{68}$ The Council and its structures have, in a variety of ways, endorsed the right of journalists not to disclose their sources, except under very narrowly defined circumstances. ${ }^{69}$ This could serve to protect journalists from being targeted as a way to prevent them from testifying as witnesses and should be applied in other jurisdictions where it is not already the case. ${ }^{70}$

65. African Charter on Human and Peoples' Rights, adopted 27 June 1981, art. 55, O.A.U. Doc. CAB/LEG/67/3 Rev. 5, 1520 U.N.T.S. 217 (entered into force 21 Oct. 1986); Protocol to the African Charter on Human and Peoples' Rights on the Establishment of an African Court on Human and Peoples' Rights, art. 6(2), adopted 10 June 1998 (entered into force 25 Jan. 2004); Inter-American Commission Rules of Procedure, art. 23; ECHR, supra note 29 , art. 34 .

66. See, e.g., Gongadze v. Ukraine, App. No. 4451/70, Eur. Ct. H.R. (2005). See also Kiliç v. Turkey, App. No. 22492/93, Eur. Ct. H.R. (2000).

67. See Press Release, Dink v. Turkey, Media Law and Freedom of Expression (14 Sept. 2010), available at http://www.mlfoe.org/Article/Detail.aspx?ArticleUid=1E58C6F4-734A4D2A-B578-A24EAC22E7EE. See also COE, Protection of Journalists from Violence (4 Oct. 2011), available at https://wcd.coe.int/ViewDoc.jsp?id=1899957.

68. See e.g., COE, Freedom of the Press and the Working Conditions of Journalists in Conflict Zones, Res. 1438 (2005), available at http://assembly.coe.int/Main.asp?link=/Documents/ AdoptedText/ta05/ERES1438.htm; see also COE, Threats to the Lives and Freedom of Expression of Journalists, Res. 1535 (2007), available at http://assembly.coe.int/main. asp?Link=/documents/adoptedtext/ta07/eres1535.htm; see also COE, Respect for Media Freedom, 6th Sess., Doc. No. 1897 (2010), available at http://www.assembly.coe.int/ ASP/Doc/XrefViewHTML.asp?FilelD=17810\&Language $=E N$.

69. COE, The Protection of "Whistle-Blowers," Res. 1729 ฯ 6.1.3.3 (2010), available at http://www.assembly.coe.int/ASP/Doc/XrefViewHTML.asp?FileID=17851 \&Language=EN; Freedom of the Press, supra note 68, 8 (v); COE, Indicators for Media in a Democracy, Res. 1636, I 8.8 (2008), available at http://www.assembly.coe.int/ASP/XRef/X2H-DWXSL.asp?fileid $=17684 \&$ lang $=$ EN.

70. See Organization of American States (OAS), Declaration of Principles of Freedom of Expression, I 9 (2000), available at http://www.oas.org/en/iachr/mandate/Basics/19. FREEDOM\%20EXPRESSION.pdf; see also Prosecutor v. Radoslav Brdjanin and Momir 
The Inter-American Court of Human Rights is currently considering a case concerning death threats as a potential violation of the right to life. ${ }^{71}$ The Inter-American Commission on Human Rights has adopted resolutions on the issue and has established a Special Rapporteur for Freedom of Expression. ${ }^{72}$ For more than a decade, the protection of journalists has been highlighted in the annual reports under the mandate. ${ }^{73}$

The African Commission on Human and Peoples' Rights has condemned violence against journalists in resolutions setting out the obligations of states, including the obligation to ensure accountability. ${ }^{74}$ In 2004, the Commission appointed the first Special Rapporteur on Freedom of Expression and Access to Information in Africa, and the mandate holders have done important work with respect to the safety of journalists on the continent. ${ }^{75}$ The establishment of the Working Group on the Death Penalty and Extrajudicial, Summary or Arbitrary Executions by the Commission provides another welcome entry point towards addressing this issue. ${ }^{76}$ The Ghanaian government led by President John Mahama, himself a trained journalist, pledged to table a draft resolution binding on member states of the African Union to protect and guarantee the safety of journalists in Africa. ${ }^{77}$

All three regional human rights courts have the authority to issue interim or provisional or preventative measures-legally binding orders to states to refrain from infringing rights, or to protect them. ${ }^{78}$ The Inter-American

Talic, Case No. IT-99-36-AR73.9, Decision on Interlocutory Appeal 9 42(11 Dec. 2002), available at http://www.icty.org/x/cases/brdanin/acdec/en/randall021211.htm, in this case, the Appeals Chamber of the International Criminal Tribunal for the Former Yugoslavia has also held that "war correspondents must be perceived as independent observers rather than as potential witnesses for the Prosecution. Otherwise, they may face more frequent and grievous threats to their safety and to the safety of their sources." Id. ๆ 42.

71. Vélez Restrepo and Family v. Colombia, Inter-Am. Ct. H.R. Case No. 12.658 at 4 (2 Mar. 2011), available at http://www.cidh.oas.org/demandas/12.658Eng.pdf.

72. See, e.g., Declaration of Principles of Freedom of Expression, supra note 70, 99.

73. See OAS, Special Rapporteurship for Freedom of Expression, available at http://www. oas.org/en/iachr/expression/index.asp.

74. See, e.g., Declaration of Principles on Freedom of Expression in Africa (2002), adopted by the Commission at its Thirty-second session, § XI; Commission's Resolution U.N. Doc. ACHPR/Res.178(XLIX) (2011) on the deteriorating situation of freedom of expression and access to information in Africa.

75. Resolution 71 on the Mandate and Appointment of a Special Rapporteur on Freedom of Expression in Africa, the African Commission on Human and Peoples' Rights Meeting at its Thirty-sixth Ordinary Session, 23 Nov.-7 Dec. 2004, Dakar, Senegal.

76. African Commission on Human and People's Rights, Res. 227, available at http://www. achpr.org/sessions/52nd/resolutions/227/.

77. IFJ, Ghana Government to Spearhead Binding Resolution on Journalists' Safety at the African Union (24 Aug. 2012), available at http://africa.ifj.org/en/articles/ghana-government-to-spearhead-binding-resolution-on-journalists-safety-at-the-african-union.

78. Protocol to the African Charter, supra note 65, art. 27(2); Rules of European Court of Human Rights, supra note 65, Rule 39; American Convention, supra note 29, art. 63. 
Commission on Human Rights as a quasi-judicial body also has the power to order precautionary measures. It has done so with the specific aim of protecting the lives of journalists in two matters during 2011, ${ }^{79}$ and four matters during 2010, ${ }^{80}$ albeit with mixed success. ${ }^{81}$ In each of these instances the Commission specifically directed the relevant states to take measures to ensure the lives of the journalists named. The African Commission on Human and Peoples' Rights has similar powers, but has not yet been asked to use them to protect journalists. These interim measures are potential access points that should be used more often by journalists who are under threat. ${ }^{82}$ Other regional inter-governmental organizations (IGOs) have also taken up initiatives with regard to the protection of journalists. The Organization for Security and Cooperation in Europe, for example, has made the safety of journalists one of its priorities. ${ }^{83}$

There are a number of emerging regional human rights systems in the world, for example the Intergovernmental Human Rights Commission of the Association of Southeast Asian Nations (ASEAN), ${ }^{84}$ the Organization of Islamic Cooperation, ${ }^{85}$ and the League of Arab States. ${ }^{86}$ It will be important to place the protection of the right to life of journalists on their agendas from an early stage. The provisions regarding the right to life in ASEAN's

79. Inter-American Commission on Human Rights, Precautionary Measures, PM 422/11: Lucía Carolina Escobar Mejía, Cledy Lorena Caal Cumes \& Gustavo Girón, Guatemala; PM 115/11: Journalists at La Voz de Zacate Grande, Honduras, available at http://www. oas.org/en/iachr/ decisions/precautionary.asp.

80. Inter-American Commission on Human Rights, Precautionary Measures, PM 36-10: Rodrigo Callejas Bedoya and family, Colombia; PM 196-09 (Extension), Inmer Genaro Chávez \& Lucy Mendoza, Honduras; PM 196-09 (Extension), Journalists from Radio Progreso, Honduras; PM 254-10, Leiderman Ortiz Berrio, Colombia, available at http:// www.oas.org/en/ iachr/decisions/precautionary.asp.

81. There have been instances of journalists being killed after precautionary measures have been granted. For example, in March 2010, Nahúm Palacios, a Honduran journalist was murdered after the state had not properly implemented precautionary measures. See Inter-American Commission on Human Rights, Precautionary Measures, Preliminary Observations of the Inter-American Commission on Human Rights on Its Visit to Honduras, 15-18, May 2010, available at http://www.cidh.org/countryrep/Honduras10eng/ Honduras10.Situation.htm.

82. While the Inter-American system is the leader on this front, the fact that its system of precautionary measures in general has been the subject of recent controversy should be pointed out. See Ministério Dad Relações Exteriores, Solicitação da Comissão Interamericana de Direitos Humanos $(\mathrm{CIDH})$ da OEA, available at http://www.itamaraty. gov.br/sala-de-imprensa/notas-a-imprensa/solicitacao-da-comissao-interamericana-dedireitos-humanos-cidh-da-oea.

83. See, e.g., William Horsley, OSCE Safety of Journalists Guidebook 5 (2012), available at http://www.osce.org/fom/85777.

84. See Ass'n. of Southeast Asian Nations, http://www.asean.org/.

85. See Org. of Islamic Cooperation, available at http://www.oic-oci.org/index.asp.

86. See Arab League Online: An Independent View on the Arab World, available at http:// www.arableagueonline.org/. 
Human Rights Declaration intends to protect the right to life in general are not encouraging. ${ }^{87}$

\section{B. International Humanitarian Law}

During armed conflict, human rights law applies as the lex generalis while international humanitarian law applies as the lex specialis. ${ }^{88}$ With respect to the right to life, the result of this interaction between the two bodies of law is that, in armed conflict, the question of whether a killing is considered "arbitrary" or unlawful is in most cases determined by international humanitarian law. ${ }^{89}$

Journalists who are members of the armed forces may be subject to targeting as is the case with soldiers or fighters in general. However, journalists who are not members of the armed forces are protected on the same basis as civilians and may not be deliberately targeted. ${ }^{90}$ War correspondents, like other journalists, are not members of the armed forces and are protected against targeting. However, they are accredited to the armed forces and, as such, qualify for prisoner of war status should they be captured. ${ }^{91}$

This protection that journalists and civilians enjoy is limited in a number of ways. Their proximity to military objectives means that their deaths in an attack could potentially be considered collateral damage provided the other conditions, such as proportionality, are met. Moreover, as is the case with civilians, the protection journalists enjoy ceases to apply when they directly participate in hostilities. ${ }^{92}$ "'Direct' participation means acts of war which by their nature or purpose are likely to cause actual harm to the personnel and equipment of the enemy armed forces." ${ }^{13}$ Journalists using their radio

87. See Press Release, UN News Centre, UN Experts Raise Concerns Over "Landmark" Southeast Asian Human Rights Declaration (16 Nov. 2012), available at http://www. un.org/apps/news/story.asp? NewsID $=43520 \& C r=$ human+rights $\& C r 1=$.

88. Legality of the Threat or Use of Nuclear Weapons, Advisory Opinion, I.C.J. RePORTS 1996, at 226, 25; Report of the International Law Commission Fifty-eighth session (1 May-9 June and 3 July-11 August 2006) General Assembly Official Records Sixty-first session Supplement No. 10 (A/61/10), p 408-410

89. Id.

90. Diplomatic Conference on the Reaffirmation and Development of International Humanitarian Law applicable in Armed Conflicts, Protocol Additional to the Geneva Conventions of 12 Aug. 1949, and relating to the Protection of Victims of International Armed Conflicts (Protocol I), art. 79, available at http://www.icrc.org/ihl.nsf/WebART/470750102?OpenDocument.

91. Geneva Convention (III) Relative to the Treatment of Prisoners of War, 12 Aug. 1949, 6 U.S.T. 3316, 75 U.N.T.S. 135, art. 4, I 4 (entered into force 21 Oct. 1950) [hereinafter Geneva Convention (III)].

92. Jean-Marie Henckaerts \& Louise Doswald-Beck, Customary International Humanitarian Law 115 (Vol. I, 2005).

93. Claude Pilloud et al., Commentary on the Additional Protocols of 8 June 1977 to the Geneva Conventions of 12 August 1949619 (1987). 
transmitters to send military messages, for example, risk placing themselves in this category. The spreading of propaganda for the enemy in itself does not make a journalist a legitimate target, but incitement to commit grave breaches of international humanitarian law, acts of genocide or violence is prohibited, and journalists spreading such messages open themselves up to being legitimate targets. ${ }^{94}$

Embedded journalists tend to be equated with war correspondents as far as targeting is concerned..$^{95}$ In its resolution 1738 (2006), the UN Security Council condemned attacks against journalists in conflict situations, and requested the Secretary-General to address, as an item in his reports to the Council, the issue of the safety and security of journalists. ${ }^{96}$

International humanitarian law is enforced through international and domestic criminal law. An intentional attack against civilians, including journalists, amounts to a grave breach of the Geneva Conventions and a war crime under the Rome Statute of the International Criminal Court. ${ }^{97}$ The primary duty, however, is on states to investigate and, if appropriate, prosecute offenders for war crimes that fall within the relevant state's jurisdiction. ${ }^{98}$ Where they are unable or unwilling to do so, the International Criminal Court has jurisdiction. ${ }^{99}$

\section{National Law}

The right to life is recognized, and murder and physical assault are proscribed, by the legal systems of states around the world. Protection of human rights is first and foremost the responsibility of national governments. However,

94. See Prosecutor v. Nahimana, Barayagwiza and Ngeze, Case No. ICTR-99-52-T, Judgment (3 Dec. 2003).

95. Alexandre Belguy-Gallois, The Protection of Journalists and News Media Personnel in Armed Conflicts, 86 INT'L Rev. Red Cross 40-41 (Mar. 2004).

96. For the latest report under Resolution 1738, Report of the Secretary-General on the Protection of Civilians in Armed Conflict S/2010/579, I 12, 16, available at http://www. securitycouncilreport.org/atf/cf/\%7B65BFCF9B-6D27-4E9C-8CD3-CF6E4FF96FF9\%7D/ POC\%20S2010\%20579.pdf.

97. Geneva Convention (I) for the Amelioration of the Condition of the Wounded and Sick in Armed Forces in the Field, 12 Aug. 1949, 6 U.S.T. 3114, 75 U.N.T.S. 31, art. 50 (entered into force 21 Oct. 1950); Geneva Convention (II) for the Amelioration of the Condition of Wounded, Sick and Shipwrecked Members of Armed Forces at Sea, 12 Aug. 1949, 6 U.S.T. 3217, 75 U.N.T.S. 85, art. 51 (entered into force 21 Oct. 1950); Geneva Convention (III), supra note 91, art. 130; Geneva Convention (IV) Relative to the Protection of Civilian Persons in Time of War, 12 Aug. 1949, 6 U.S.T. 3516, 75 U.N.T.S. 287, art. 147 (entered into force 21 Oct. 1950); Rome Statute of the International Criminal Court, adopted 17 July 1998, art. 8, I 2 (a)(i), (e)(i), U.N. Doc. A/CONF.183/9 (1998), 2187 U.N.T.S. 90 (entered into force 1 July 2002) [hereinafter Rome Statute].

98. Henckaerts \& Doswald-Beck, supra note 92, at 607.

99. Rome Statute, supra note 97, art. 17. 
the effective implementation of the international norms at the national level varies-hence the importance of international supervision as a "second layer" of defense.

Impunity was identified above as one of the main reasons for the high incidence of murders of journalists in some societies. With the narrow exception of international criminal prosecutions, mentioned above, prosecutions take place within states and it is at this level that a system's deficiencies are often located and has to be addressed. In this regard, the norms set out above concerning proper investigation and prosecution must be followed.

There are various reasons why those who attack journalists are not brought to justice in some domestic legal systems. These reasons include: undue influence on the criminal justice system through corruption; intimidation and complicity of those who run the systems, such as the police, prosecutors and judges; and also on witnesses and civil complaints mechanisms. Such influence may be exerted for example by politicians, bureaucrats, drug cartels, or criminals. Impunity can result from the failure to investigate or to prosecute, the acquittal of a guilty person, inappropriately lenient sentences, or an early release of someone who has been convicted and sentenced.

Undue influence is applied more easily at the local level than at the national level, because of the close interaction between those who may want to manipulate the system and those whom they target, such as witnesses or officials. In a positive development, Mexico is now in the process of passing a constitutional amendment that will proscribe the killing of journalists at the federal level, rather than at the state level ${ }^{100}$ and Brazil has initiated a similar process. ${ }^{101}$ This is an example of how the issue can be elevated from the local to the national level within a country. Additionally, Guatemala has initiated a process to create a prosecutor's office for attacks against journalists. ${ }^{102}$

In general crimes against journalists should be regarded as priority crimes, and be investigated by specialized units.

In addition to certainty of conviction, deterrence depends on severity of sentences. Targeting journalists based on their social function should be regarded as an aggravating circumstance. ${ }^{103}$ Such an approach fits in with

100. Mike O'Connor, Mexican Senators Say Journalist Murders to be Federal Crime, CPJ Blog, available at http://cpj.org/blog/2012/03/mexican-senators-say-journalist-murders-to-befede.php.

101. See Press Freedom: Safety of Journalists and Impunity UNESCO, 11(2007), available at http://unesdoc.unesco.org/images/0015/001567/156773e.pdf; see also, Inter-American Press Association Resolution, IAPA Midyear Meeting, 20-23 Apr. 2012, Cádiz, Spain Impunity Brazil, available at http://www.sipiapa.org/v4/det_resolucion.php?asamblea= 48\&resid=717\&idioma $=$ us.

102. Written Comments of Article 19, Global Campaign for Free Expression, and Centro Civitas for the Review of Guatemala's Third Periodic Report to the Human Rights Committee in Compliance with Article 40 of the International Covenant on Civil and Political Rights I 15 (Sept. 2010).

103. Other human rights considerations such as concerns about the imposition of the death penalty should be kept in mind. 
the reverse chilling effect described above. However, the idea that is sometimes expressed that crimes against journalists should be regarded a new category of "crimes against humanity" takes the idea of elevating the issue too far and may dilute the small number of truly exceptional crimes that belong in this category-except where the conditions of the existing crimes against humanity are met. ${ }^{104}$

Even in highly repressive societies courts can sometimes provide useful entry points for an active civil society when it is not available in the political realm. In 2011, there were, for example, political attempts in Nepal to have charges dismissed against ruling party cadres with respect to the abduction and murder of a journalist. The Supreme Court overruled this, after civil society took legal action. ${ }^{105}$

Many national legal systems provide for some form of interim measures or restraining orders. In some cases it may be appropriate for journalists who feel threatened to apply for such interim measures. The fact that these orders are legally binding could have a restraining effect, and it also serves to raise public awareness of the plight of the person concerned. Moreover, habeas corpus, amparo, and other similar procedures may save lives. ${ }^{106}$

In some cases national human rights institutions (NHRIs) are well placed to pursue the protection of journalists from attack, inter alia by raising awareness and taking up matters with the government. The principles relating to the status of national institutions for the promotion and protection of human rights (Paris Principles) provide that NHRIs may be authorized to receive and act upon individual complaints, and may in appropriate cases be in a position to assist a journalist under threat, or to address impunity. ${ }^{107}$ Public protectors or ombudspersons in some countries have the same function.

Some states provide protective programs for witnesses and other members of society who are at risk, such as journalists and human rights defenders. This can save lives, not only in societies where there is a generally high level of protection of life, but also where the institutions of state are under pressure or heavily compromised. Colombia has initiated, with some success, a program for the protection of those at risk, including journalists. ${ }^{108}$

104. Rome Statute, supra note 97, art. 7.

105. In Nepal, Killers of Journalists Could go Free, Letter from the Executive Director of CPJ to the Prime Minister of Nepal, available at http://cpj.org/2011/09/september-15-2011-primeminister.php.

106. For an explanation on habeas corpus, see http://www.amnestyusa.org/our-work/issues/ security-and-human-rights/illegal-and-indefinite-detention/habeas-corpus; on amparo, see Allan R Brewer-Carías, The Latin American Amparo Proceeding and the Writ of Amparo in the Philippines, 1 City Univ. Hong Kong L. Rev. 73 (2009).

107. Principles Relating to the Status of National Institutions (The Paris Principles), G.A. Res. 48/134 (adopted 20 Dec. 1993), see section Additional Principles Concerning the Status of Commissions with Quasi-Jurisdictional Competence, available at http://www2.ohchr. org/english/law/parisprinciples.htm.

108. See CPJ, Attacks on the Press 2002: Colombia, available at http://cpj.org/2003/03/ attacks-on-the-press-2002-colombia.php. 
Honduras is reported to have initiated the process to start a similar program. In this case, the journalists in question remain in the society, but are placed under nationally sanctioned protection. ${ }^{109}$

In some cases states also provide protection for those from other countries. The government of Sweden, within the context of its Special Initiative for Democratization and Freedom of Expression, funded a safe house for journalists in Kalmar, Sweden. ${ }^{110}$ In this example, the journalists are removed from their society altogether.

Governments can use diplomatic channels and diplomatic protection to address the plight of their nationals in other countries. Moreover, states can also take action against individuals who target journalists (or allow them to be targeted). An example of such a sanction would be for states to refuse visas to these individuals, which could be very effective in some circumstances.

While the entry points outlined above, on the national and international level, may be used to secure the safety of journalists, it is also true that in some societies they will be of little value, or could even serve as a catalyst for the opposite effect from the one sought.

\section{Additional Mechanisms and Methods}

As the above overview demonstrates, there are no obvious gaps in the international legal framework for the protection of journalists. The main problem lies with the implementation of these norms and the creation of appropriate structures at the national level. Failure to implement can be attributed partially to ignorance, requiring awareness-raising on the problem and the applicable norms, as well as to a lack of political will. Here the general principle is that the issue must be elevated from the local level to a higher level. It is therefore important to ensure that international governmental and civil society structures keep the issue on their agendas.

There are a variety of avenues outside the realm of the legal and intergovernmental structures outlined above, and ways of engaging with them, that can serve to protect journalists. A number of international NGOs worldwide focus on the issue of protecting journalists. These include, inter alia, CPJ, IFJ, INSI, RWB, and the Press Emblem Campaign. ${ }^{111}$ Others have a broader

109. See Jeremy Dear, Ten Suspects Arrested in Connection With Honduras Reporter Murder, GuARDIAN, 31 May 2012, available at http://www.guardian.co.uk/media/2012/may/31/ suspects-arrested-honduras-reporter-murder.

110. FOJO: Mediinstitutet, Safe House, available at http://www.fojo.se/international/international-projects/safe-house. The Safe House was administered by the Fojo Media Institute in Kalmar, Sweden.

111. See Press Emblem Campaign, Contact the Press Emblem Campaign, available at http:// www.pressemblem.ch/4902.html. 
focus, such as freedom of expression in general, but also include the safety of journalists in their work, for example Article 19. ${ }^{112}$ Similar work is done by local organizations. Some examples of organizations in the Russian Federation are: the Russian Union of Journalists, ${ }^{113}$ the Glasnost Defence Foundation, ${ }^{114}$ and the Centre for Journalism in Extreme Situations. ${ }^{115}$

In addition to general advocacy and the provision of statistics, such as the ones provided above, the following aspects of their work may be highlighted:

1) A wide array of safety codes have been developed, which enable journalists to protect themselves. This includes the INSI Safety Code of $2007^{116}$ and the RWB Charter for the Safety of Journalists Working in War Zones or Dangerous Areas of 2002. ${ }^{117}$

2) UNESCO as well as some news organizations and NGOs, for example IFJ, INSI and Article 19, provide journalists with safety training, which includes risk awareness and avoidance and first aid. ${ }^{118}$

3) The International Committee of the Red Cross (ICRC) provides first-aid courses for journalists in cooperation with national Red Cross and Red Crescent Societies, and training on international humanitarian law. ICRC is currently developing a new tool on the training of journalists. ${ }^{119}$

4) RWB has established a 24-hour emergency contact point for journalists in trouble. ICRC provides a permanent hotline and e-mail contact to report a missing, wounded, or detained journalist and request assistance. ${ }^{120}$

112. See Article 19, available at http://www.article19.org.

113. See http://www.ruj.ru (Russian only).

114. See Glasnost Defense Foundation, General Information on the GDF, available at http:// www.gdf.ru/about.

115. See Center for Journalism in Extreme Situations, available at http://cjes.org/ about/?lang=eng.

116. See International News Safety Institute, http://www.newssafety.org/page. php?page $=20450 \&$ cat=press-room-news-release.

117. See Charter for the Safety of Journalists Working in War Zones or Dangerous Areas, available at http://www.rsf.org/lMG/doc-1288.pdf. The "Green Book" issued by the Ministry of Defence, United Kingdom provides a positive example by providing clear instructions on how military staff must treat media workers in the field. See MinISTRY OF Defence, Green Book, available at http://www.army.mod.uk/documents/general/GreenBook. pdf.

118. Intergovernmental Council of the International Programme for the Development of Communication, The Safety of Journalists and the Danger of Impunity: Report by the Director-General 11 (2012); see also World Movement for Democracy, What is Being Done on the Protection of Journalists, available at http://www.wmd.org/resources/whatsbeing-done/protection-journalists.

119. ICRC, AnNual Report 2011, at 65 (2011), available at http://www.icrc.org/eng/assets/files/ annual-report/icrc-annual-report-2011.pdf.

120. See Reporters Without Borders, http://en.rsf.org/a-hotline-for-journalistsin-17-04-2007,21749.html, for the ICRC hotline, see http://www.icrc.org/eng/resources/ documents/misc/hotline-010106.htm. 
5) One of the high-profile activities of CPJ is its support for journalists forced to go into hiding. ${ }^{121}$ ICRC plays an ongoing role, for example in tracking missing journalists and evacuating wounded journalists. ${ }^{122}$

Further support that some journalists receive from NGOs, employers, or others includes loans of equipment, evacuation, medical care, counseling, and support for families. Security of communications is another important area. Taken together, such measures of support place journalists, even where they do not use them but simply know they are available, in a much stronger position to express them.

A quick overview of some of the above-mentioned emergency entry points are available on the website provided in the footnote below. ${ }^{123}$

\section{CONCLUSION}

The fairness, objectivity, and professionalism of the reporting done by journalists in exercising their role of informing the world remains the bedrock of a profession and activity that plays a central role in ensuring thriving societies. While individual journalists may not always adhere to these standards, and should be held accountable when they do not, the profession and practice of journalism plays a central role in the well-being of society and as such it deserves special protection. Care should be taken, however, not to make professionalism a precondition for the protection of the right to life of journalists - even those who do not adhere to these standards have a right not to be unlawfully killed.

The general approach advocated in this article is that in addition to local efforts to address the safety of journalists, the issue should be moved up to the next level, and be placed in the national or international spotlight. The nature of the threats journalists face invariably requires attention and action at higher scales of authority. Their situation should be taken to the national level, and in appropriate cases, the international level, to ensure outside scrutiny. This can be done in a variety of ways; some focusing on the plight of journalists in general, others on individual cases. Significant changes in the substantive legal provisions of international law related to

121 See CPJ, Defending Journalists Worldwide, What We Do, available at http://cpj.org/ campaigns/assistance/what-we-do.php.

122. Charter for the Safety of Journalists, supra note 117, at 65; see also Interview with Robin Geiss, ICRC, How Does International Humanitarian Law Protect Journalists in ArmedConflict Situations?" (27 July 2010), available at http://www.icrc.org/eng/resources/ documents/interview/protection-journalists-interview-270710.htm.

123. See Emergency Contact List for Journalists at Risk, available at http://web.up.ac.za/ sitefiles/file/47/15338/Emergency\%20Contact\%20List\%20for\%20Journalists\%20at\%20 Risk_updated.pdf. 
the protection of journalists are not necessary; the challenge lies rather with the implementation of the existing normative framework at the international (including regional) and national levels. There does not appear to be a need for a new global treaty dealing specifically with the safety of journalists. ${ }^{124}$ However, a soft-law instrument such as a UN declaration or resolution would help to elevate the issue in general and draw the attention of regional and international institutions and frameworks to the topic.

There is considerable scope for journalists in countries that are part of regional human rights systems or mechanisms to take up the matter, for example through the existing special procedures and, to some extent, through interim measures. The same applies for the UN mechanisms that cover all countries. On the domestic level, national as opposed to local investigations and prosecutions as well as protective programs may be required.

Local journalists and foreign correspondents play complementary, not necessarily adversarial, roles. While journalists based in their home countries have local legitimacy as commentators and can offer an insider's view, foreign correspondents are often also well placed to attract international attention to the issues they investigate. While the local journalists are often more vulnerable, foreign correspondents may prove to be more difficult to silence. Foreign correspondents can, in some cases, continue to spread the message and also attract attention to the plight of their local colleagues. ${ }^{125}$ There is, however, an under-appreciation of the dangers faced by local journalists, and the fact that they are most at risk.

The primary objective should be prevention, and the statistics provided above suggest that this may be possible in more cases than is often recognized. Accountability, with its strong justice dimension, should not be regarded as standing in contrast to prevention-accountability is also the key to preventing recurrence. Systematic impunity is probably the main cause of the killing of journalists, and accountability should by extension be a primary focus of any campaign to ensure the protection of the lives of journalists.

On the domestic level, there are significant shortcomings in many countries in the implementation in domestic law of the international normative framework. This is especially true in terms of accountability frameworks,

124. One of the main proposals for a new instrument comes from the Press Emblem Campaign, who argues for a specific emblem which may be carried by journalists in time of war. See Joanne M. Lisosky \& Jennifer Henrichsen, Don't Shoot the Messenger: Prospects for Protecting Journalists in Conflict Situations, 2 Media, War \& Conflict 138 (2009). Some of the problems associated with this proposal include the fact that it may make it easier for journalists to be targeted, it could dilute the significance from existing emblems, such as those of the International Red Cross and Red Crescent Movement, and those who wish to have such an emblem can simply put a banner marked PRESS on their arms, without treaty reform.

125. See, e.g., Dangers Faced by Journalists in Mexico, CNN, 29 Feb. 2012, available at http://cnnpresents.blogs.cnn.com/2012/02/29/dangers-faced-by-journalists-in-mexico/. 
which relate to the certainty of conviction and the imposition of a sentence of sufficient severity.

Comprehensive and effective safeguards to prevent physical threats against journalists and to ensure accountability should be established and regarded as a priority in terms of focus and resources. A clear public stand should be taken at the highest level of government to condemn executions of journalists and threats to their lives, and to re-emphasize the important role of journalists in society.

States have the obligation to conduct prompt and exhaustive investigations into all suspected cases of violations of the right to life of journalists and to identify and bring to justice those responsible, not only the actual perpetrators but also the "masterminds" who initiate the attacks. The investigations and judicial proceedings should be conducted impartially, in the absence of improper influences, pressures, threats, or interferences. Statutes of limitation should not allow prosecutions to be blocked. In appropriate cases, more severe sentences may be called for where journalists were targeted.

Where there is a pattern of killing of journalists, states should take special measures to address this issue in a systematic way, and should be scrutinized with respect to those measures by the relevant human rights mechanisms and international community.

It is not enough that governments and others are told that journalists need protection. They have to understand that this is needed because of the social role that journalists play. Constant and effective advocacy, backed up by statistics, is required. Journalists and their families should be given the opportunity to benefit from protection programs, including witness protection programs, which operate efficiently and on a rapid-response basis. This may have to be done on a national as opposed to a local level to be effective.

The safety of journalists should not be seen in isolation, as a right to life issue only. Their safety is inextricably tied to the status of their profession in society, and to the protection of the other rights tied to the exercise of their profession. The likelihood that a state will be successful in protecting journalists depends on the extent to which there is general appreciation of the importance of freedom of expression in the society, other rights to bodily integrity are recognized, legislation that enables protection of these rights is in place, the rule of law prevails, and the political will to protect journalists exists and is seen to exist. Violence against journalists thrives where freedom of expression is absent. 